\title{
Another reason for abdominal pain: mesenteric panniculitis
}

\author{
Ali Kemal Sivrioglu, ${ }_{1}^{1}$ Muzaffer Saglam, ${ }^{2}$ Mehmet Deveer, ${ }^{3}$ Guner Sonmez ${ }^{2}$
}

${ }^{1}$ Department of Radiology, Aksaz Military Hospital, Mugla, Turkey

${ }^{2}$ Department of Radiology, GATA Haydarpasa Teaching Hospital, Istanbul, Turkey

${ }^{3}$ Department of Radiology, School of Medicine, Mugla Sitki Kocman University, Mugla, Turkey

\section{Correspondence to} Dr Ali Kemal Sivrioglu, draksivrioglu@gmail.com
To cite: Sivrioglu AK, Saglam M, Deveer M, et al. BMJ Case Rep Published online: [please include Day Month Year] doi:10.1136/ bcr-2013-009305

\section{DESCRIPTION}

A 50-year-old man was admitted to an emergency department with umbilical abdominal pain. His medical history included nothing of particular note. Physical examination revealed a mild abdominal distention and a palpable mass in the left upper quadrant. Laboratory tests only showed increased erythrocyte sedimentation rate $(35 \mathrm{~mm} / \mathrm{h})$. Abdominal ultrasonography showed multiple mesenteric lymph nodes and increase in the mesenteric echogenicity. On contrast-enhanced abdominal CT imaging, a hyperattenuated fatty mass encasing a misty mesentery (non-specific sign, increased attenuation of the mesentery), multiple mesenteric lymph nodes, preservation of fat around vessels and lymph nodes (fat ring sign), pseudocapsule (peripheral band of soft tissue attenuation) and displaced bowel loops were seen at the mesenteric root in the left upper abdominal quadrant (figures 1-4). These findings were compatible with mesenteric panniculitis. The patient was only treated with drug therapy intended for symptoms.

Mesenteric panniculitis is a rare disorder characterised by a chronic non-specific inflammation involving the adipose tissue of the bowel mesentery. ${ }^{1}$ The exact aetiology remains unknown. ${ }^{2}$ The possible causative factors are autoimmunity, infection, trauma, ischaemia, prior abdominal surgery and neoplasm. Prevalence is $0.6 \% .^{2}$ Sclerosing mesenteritis is classified into three types based on the predominant tissue type in the mass: mesenteric panniculitis (chronic/acute inflammation and fat necrosis more than fibrosis), mesenteric lipodystrophy (fat necrosis more than inflammation and

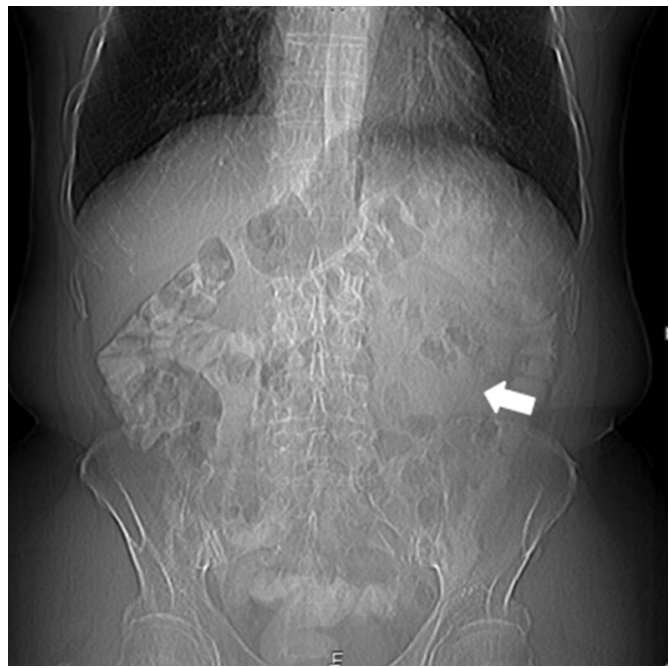

Figure 1 CT scanogram showing displaced bowel loops (arrow) in the left upper abdominal quadrant.

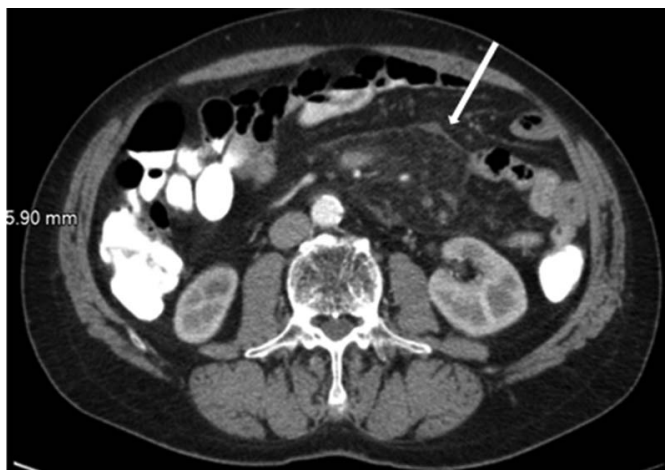

Figure 2 Axial contrast-enhanced CT image showing a hyperattenuated fatty mass with pseudocapsule (arrow) at the mesenteric root.

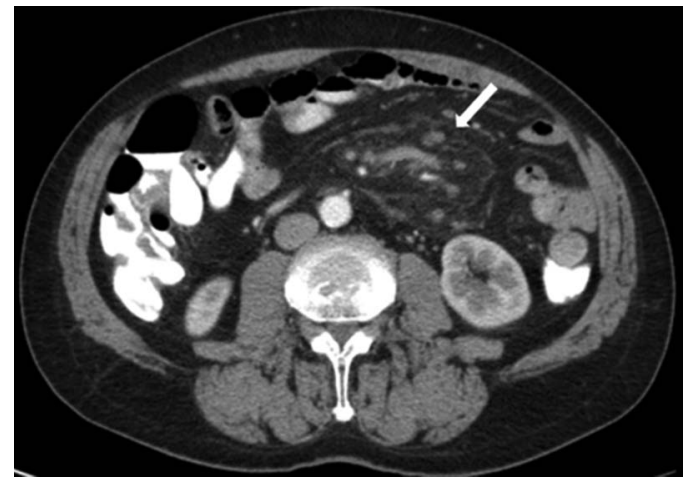

Figure 3 On axial contrast-enhanced CT image, multiple mesenteric lymph nodes and preservation of fat around vessels and lymph nodes (fat ring sign, arrow) are seen in the hyperattenuated fatty mass.

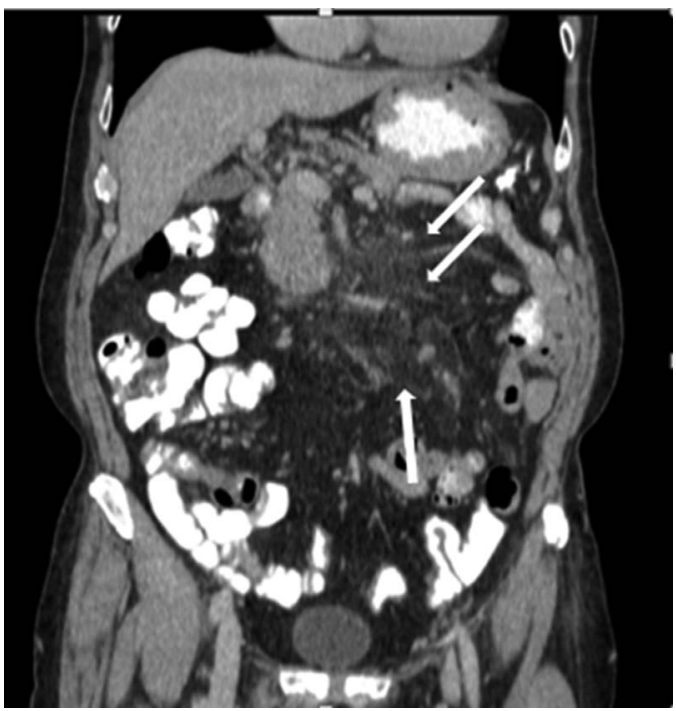

Figure 4 Coronal contrast-enhanced CT image showing a hyperattenuated fatty mass at the mesenteric root (arrows). 
fibrosis) and retractile mesenteritis (fibrosis/retraction more than inflammation/fat necrosis). The associated abnormalities are idiopathic inflammatory disorders such as retroperitoneal fibrosis, sclerosing cholangitis, Riedel thyroiditis and orbital pseudotumour. ${ }^{3}$ CT plays an important role in suggesting the diagnosis in the proper clinical setting and can be useful in distinguishing sclerosing mesenteritis from other mesenteric diseases. ${ }^{3}$

\section{Learning points}

Mesenteric panniculitis is a rare disorder characterised by a chronic non-specific inflammation involving the adipose tissue of the bowel mesentery.

- Sclerosing mesenteritis is classified into three types based on the predominant tissue type in the mass: mesenteric panniculitis, mesenteric lipodystrophy and retractile mesenteritis.
Competing interests None.

Patient consent Obtained.

Provenance and peer review Not commissioned; externally peer reviewed.

\section{REFERENCES}

1 Bush RW, Hammar SP, Rudolph RH. Sclerosing mesenteritis: response to cyclophosphamide. Arch Intern Med 1986;146:503-5.

2 Daskalogiannaki M, Voloudaki A, Prassopoulos $\mathrm{P}$, et al. CT evaluation of mesenteric panniculitis: prevalence and associated diseases. AJR 2000;174:427-31.

3 Horton KM, Lawler LP, Fishman EK. CT Findings in sclerosing mesenteritis (panniculitis): spectrum of disease. RadioGraphics 2003;23:1561-7.

Copyright 2013 BMJ Publishing Group. All rights reserved. For permission to reuse any of this content visit http://group.bmj.com/group/rights-licensing/permissions.

BMJ Case Report Fellows may re-use this article for personal use and teaching without any further permission.

Become a Fellow of BMJ Case Reports today and you can:

- Submit as many cases as you like

- Enjoy fast sympathetic peer review and rapid publication of accepted articles

- Access all the published articles

- Re-use any of the published material for personal use and teaching without further permission

For information on Institutional Fellowships contact consortiasales@bmjgroup.com

Visit casereports.bmj.com for more articles like this and to become a Fellow 